\title{
Varlık ve Hiçlik Bağlamında Jean-Paul Sartre’ın Estetik Teorisi
}

\section{Sartre's Aesthetic Theory in the Context of Being and Nothingness}

\author{
Nermin Urganc1 ${ }^{1}$ (])
}

'Doktora Öğrencisi, Dokuz Eylül Üniversitesi, Sosyal Bilimler Enstitüsü, Felsefe Anabilim Dalı, İzmir, Türkiye

\section{ORCID: N.U. 0000-0002-7253-009X}

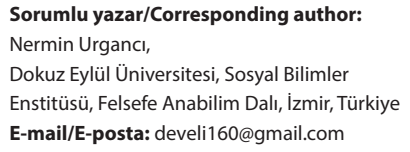

Başvuru/Submitted: 02.02 .2020

Revizyon Talebi/Revision Requested: 21.03.2020

Son Revizyon/Last Revision Received: 20.05.2020

Kabul/Accepted: 21.05 .2020

\section{Atıf/Citation:}

Urganci, Nermin. (2020). “Varlık ve Hiçlik Bağlamında Jean-Paul Sartre'ın Estetik Teorisi" Felsefe Arkivi-Archives of Philosophy, 52: 59-81. https://doi.org/10.26650/arcp2020-004

\begin{abstract}
ÖZET
Jean-Paul Sartre (1905-1980) yaşadığımız çevreye, olaylara tarafsı kalma veya sorumsuz davranabilme intimalini reddeden ve bu düşüncesini temel yapıtı Varlık ve Hiçlik'te (Fenomenolojik Ontoloji Denemesi) (1943) varlığın anlamını sorgularken, insan varlığının, varolmasındaki süreçte önceden belirlenmiş öz düşüncesini yok sayar. Sartre’a göre, insanın kendi varlığı ve diğer varolanlar arasındaki ilişkiyi anlama çabası, varoluşunu inşa etme süreci, sadece hümanist ateist bir varoluşçu çizgi ile mümkün olacaktır. Bu çalışma öncelikli olarak, varoluş felsefesinin ahlak alanına bakışını inceleyerek varolan tüm değerlerin yeniden oluşturulma talebini ele alır. Daha sonra, Sartre'ın estetik teorisine ilişkin görüşlerini Edebiyat Nedir? (1947) ve Estetik Üzerine Denemeler (1963) yapıtı ile ortaya koymayı amaçlamaktadır. İnsanlığa yön veren, onları harekete geçiren, ontolojik varlığını belirleyen sanat, Sartre'a göre başıboş, tasmasız bir köpek gibi davranamaz. Onun bağlı olma, özgürlük talebinde bulunma ve topluma angaje olma özelliği vardır. Bu çağrı tüm sanat dalları için özgürlüğe yöneliktir. Özgürlüğe ilişkin yapılan bu çağrı sorumluluk bilincinden bağımsız düşünülemez. Sartre'a göre bir özgürlük talebi olarak bu sanatsal eylemden hepimiz sorumluyuz, sanatçı da bu sorumluluğa hizmet edecek olandır. Böylelikle Sartre, Ontoloji Denemesini, Estetik yapıtında somut örnekler vererek, olanak ve uygulanabilirliğini göstermiş olur. Son olarak bu çalışma, işaret edilen iki metin arasındaki bağlantı ile birlikte Fenomenolojik Ontolojik Deneme'ye hizmet edip edemeyeceğini gösterme peşindedir.
\end{abstract}

Anahtar Kelimeler: Varlık, hiçlik, estetik, edebiyat, plastik sanatlar, sanatçı, varoluş, boşluk, öz

\section{ABSTRACT}

Jean-Paul Sartre (1905-1980) rejecting the possibility of being impartial or irresponsible regarding our environment and the events taking place where we live, questions the meaning of being in his basic work, Being and Nothingness (Phenomenological Ontology Essay) (1943), and ignores a predetermined idea of self in the process of existence of the human being. According to Sartre, the effort to understand the relationship between one's existence and other existences, and the process of building this existence will only be possible with a humanist 
atheist existentialist line. This study primarily addresses the demand for reconstruction of all existing values by examining the view of the philosophy of existence to the moral field. Later, our intention is to use Sartre's views on aesthetic theory in What is Literature? (1947) and Essays on Aesthetics (1963) to reveal his studies. According to Sartre, the art that guides humanity, that drives it, that determines its ontological existence, cannot act like a stray, leash-free dog. It can be connected, demand freedom, and engage with society. This announcement is aimed at freedom for all branches of art. This call for freedom cannot be considered independent of responsibility. To Sartre, we are responsible for this artistic act as a demand for freedom, and the artist is the one who will serve this responsibility. Thus, Sartre demonstrates the possibility and applicability of the Ontology Essay by giving concrete examples in his aesthetic study. Finally, this study seeks to show whether it can serve the Phenomenological Ontological Essay along with the link between the two texts marked..

Keywords: Being, nothingness, aesthetics, literature, plastic arts, artist, existence, emptiness, self

\section{Giriş}

"Özgürlük araştırma(sı)" cısı olan Sartre’a göre insan, Tanrı tarafından veya başka bir şey aracıllğıyla ne olacağı önceden belirlenmiş bir varolan olarak dünyaya gelmez. $\mathrm{O}$ "dünyaya terkedilmiştir (İng. Forlorn).”2 Bu terkedilmişlik içinde her şeyi anlamlandırma insana bahşedilir. Bu özellik Sartre tarafından insanın her alanda eyleyen, etken veya seyirciden çok bir aktör olarak betimlenmesine neden olur. Anlamsızlğın içine düştüğümüz her anda eylemin sorumluluğunu üstlenerek ne ile karşı karşıya olduğumuzu belirleyebilme aşamasında Sartre'a göre bir içdaralması, elem (Fr. Angoisse) yaşarız. "Ne yapacağım ben? Ne yapacağım ben şimdi??" diye paniğe kapılırız ancak tam da buradaki terkedilmişlik içinde özgür olduğumuzun bilincine varmakla şeyleri belirleyebilme sorumluluğunu üstlendiğimizi fark ederiz. "İnsan, özgürlüğünün bilincine içdaralması içinde varır; ya da başka bir deyişle, içdaralması, varlık bilinci olarak özgürlüğün varlık kipidir."” Özgürlük ve içdaralmasının birbirine bu yakınlığı, insana daima yapıştırılmaya çalışılan değerler dünyasından kopuşunu gösterir. Böylelikle şimdiden insan, özgür olarak eyleminin hem nedeni hem de sonucu olmakla tek başına bırakılmışıtır. Burada insan sadece kendisinin yalnız olduğunu düşünmemekle birlikte, diğerleriyle bir arada, onlara ilgi duyup onlarla kaygılanan bir konuma yerleşmiştir. Sartre kendisine yöneltilen eleştirilerin başında "insanı, kendi başına, dipsiz bir yalnızlık içinde düşünmekle" itham eden fikirlere karşılık, varoluşçuluğun bir yalnızlık felsefesi değil, "bütün insanlık için karar veren bir yasa koyucu olduğunun ayırdında olarak kendisini herhangi bir şeyle bağladığı zaman - böyle bir anda, tam ve derin bir sorumluluk duygusundan kurtulamaz." ${ }^{\prime}$ Ancak Sartre, her insanın aynı içdaralmasını yaşadığını ifade etse de herkesin aynı sorumluluk bilinciyle hareket etmediğinin altını çizer. Sartre için bu tarz insanların, "bir başkası da benim yerime düşünebilir" rahatlığıyla içdaralmasını bastırdığını, hatta bunu maskelediğini

1 Metin Bal, "Varoluş̧̧uluk ve Hümanizm” (1946) Yazısında Sartre’ın Varoluşçuluk Savunması, Dokuz Eylül Üniversitesi, Doktora Programı, Felsefe Anabilim Dalı, Sanatta Modernizm ve Postmodernizm Ders Notları, 24.04.2019, s.1.

2 Bal, "Varoluşçuluk ve Hümanizm” (1946) Yazısında Sartre’ın Varoluşçuluk Savunması, s. 10.

3 Jean-Paul Sartre, Varlık ve Hiçlik (Fenomenolojik Ontoloji Denemesi), Çev. Turhan Ilgaz, Gaye Ç. Eksen, İstanbul, İthaki Yayınları, 2011, s.80.

4 Sartre, Varlık ve Hiçlik (Fenomenolojik Ontoloji Denemesi), s.79.

5 T.S. Eliot, Hümanizmin Özü, "Jean-Paul Sartre, Varoluş̧uluk Bir Hümanizmdir”, Çev. Ahmet Aydoğan, İstanbul, İz Yayıncilik, 2002, s.100.

6 Eliot, Hümanizmin Özü, “Jean-Paul Sartre, Varoluş̧̧uluk Bir Hümanizmdir”, s.106. 
söyleyebiliriz. Maskelemenin insanın kendi kendisini aldatmasından (İng. Bad faith, Fr. Mauvaise foi) başka bir anlamı yoktur. Sartre şöyle söyler; "Bilmezden gelmek için kaçarım ama kaçtığımı bilmezden gelemem ve içdaralmasından kaçmak içdaralmasının bilincine varmanın bir kipinden başka bir şey değildir. Dolayısıyla içdaralması tam anlamıyla ne maskelenebilir ne de ondan kaçılabilir." İnsan ile eylemin sorumluluğu arasına perde çeken kendini aldatma durumu, "ben ve bir başkası, bir aldatan ve aldatılan ikiliği söz konusu değildir. Kendini aldatmada ben, bizzat hakikati kendisinden gizleyendir. Sadece bilinç, kendini aldatır." "İnsanın bu kendini aldatma durumundan sıyrılması, içdaralmasını göstermesiyle başlar. Varolanın kendini sıkıntı, bulantı (İng. Nauesa, Fr. La nausée) duygularıyla açığa çıkarması Sartre’a göre yalnızca özgür insan için olanaklı olacaktır, çünkü her bir olumsuzlama veya hiçleştirme insanın bütün olarak tamamlanmadığını gösterir. "Kendisi için varlık kendine varlık’n olumsuzlanması (nègation) olarak tezahür eder ve bilgi edimiyle varlığın içine olumsuzlamayı sokar. [...] Bir şeyin bilinç için mevcut olması "olumsuzlama" (nègation) yani hiçleme (nèantisation) ile mümkün olur." $\mathrm{Bu}$ durumda kendi için varolan üzerinde taşıdığı namevcut olma haliyle hep eksik kalacaktır. Varoluşu bitmemiş insan için oluşan her firsat, böylece bir özgürlük imkânı sunar. Sartre’a göre insan, bitmiş bir proje olmadığına göre varlığına musallat olmuş hiçlikle yaşamaya mahkûmdur. İşte bu durum insanı diğer şeylerden ayırarak özgürlüğünü ortaya çıkarır. Özgürlük sadece tek bir insanın karşı karşıya kaldığı durum değildir. "İnsanın varlığı ile özgür oluşu”10 arasında hiçbir farkın olmaması, kendi var olmamdaki özgürlük ötekinin varlığındaki özgürlükle birlikte hareket etmektedir. "Özgürlük, başkalarına bağlı olmamaktır, fakat bir bağlanma (İng. Commitment, Fr. Engagement) ortaya çıkar çıkmaz, kendimi ve başkalarının özgürlüğünü kendiminkiyle aynı anda hissetmeye yükümlü hissederim. Başkalarının özgürlüğünü de kendi hedefim haline getirmedikçe, özgürlüğü hedefim haline getiremem." ${ }^{11}$ İnsanın hem kendi özgürlüğünü hem de başkalarının özgürlüğünü göz önüne alma mahkûmiyeti Sartre’a göre sorumluluğun ilk ölçütlerindendir. Sorumluluğun ve özgürlüğün biraradalığı, bizi doğrudan eyleme yönlendiren nedenlerdir. Her eylem, seçim veya kararda sorumluluk ve özgürlük bilinciyle hareket ederiz. Sartre insan varoluşunun özgür olduğu düşüncesini "eylem”e dayandırır, çünkü “insanın özgür bir varolan olmasının kanıtı "eylem” dir, "eylem bir olanaklar çokluğunun var olduğunu” gösterir ve bir kimse bu eylemler çokluğundan birini yapmayı seçer. Bir kimsenin her durumda bir seçim ve kararla karşı karşıya kalması kaçınılmazdır. Eylemde bulunmak "dünyanın biçimini iyileştirecek şekilde değiştirmek"tir." ${ }^{2}$ Böylece şimdiden varoluşçuluğun, insanı umutsuzluktan

7 Jean-Paul Sartre, Varlık ve Hiçlik (Fenomenolojik Ontoloji Denemesi), Çev. Turhan Ilgaz, Gaye Ç. Eksen, İstanbul, İthaki Yayınları, 2011, s.97.

8 Funda Abalı, Jean-Paul Sartre’ın Tiyatro Yapıtlarında Varoluş̧u Felsefe ve Fenomenolojik Sanat Anlayışı, Yayımlanmış Yüksek Lisans Tezi, Dokuz Eylül Üniversitesi, İzmir, 2017, s,83.

9 Emre Şan, Sartre ve Giacometti: Varoluş̧u Sanat Üzerine Düşünceler, Felsefe Düşün Akademik Felsefe Dergisi, Sayı: 12, 2019, s.203.

10 Jean-Paul Sartre, Varlık ve Hiçlik (Fenomenolojik Ontoloji Denemesi), Çev. Turhan Ilgaz, Gaye Ç. Eksen, İstanbul, İthaki Yayınları, 2011, s.75.

11 T.S. Eliot, Hümanizmin Özü, "Jean-Paul Sartre, Varoluş̧uluk Bir Hümanizmdir”, Çev. Ahmet Aydoğan, İstanbul, İz Yayıncilık, 2002, s.128.

12 Metin Bal, Sartrém Varoluş̧u Felsefesi ve Dava Edebiyatı Teorisi, Felsefe Arkivi - Archives of Philosophy, Sayı: 50, İstanbul Üniversitesi Yayını, 2019, s.20. 
çok yaşamaya, burjuva felsefesi olmaktan çok her eyleminin bir çevreyi ve insancıl özelliği kucakladığını, bir çocuğun gülümsemesini unutmaktan öte insan varlığının anlamını sorgulayan bir metafizik olduğunu söyleyebiliriz. Fenomenolojik Ontoloji Denemesi nin eylem öğretisi olarak kendini bu belirleme yönü Sartre için "varoluşun özden önce geldiğinin"13 kanıtıdır. "İnsan var olur önce. Bir geleceğe doğru atılan ve bu atılışın bilincine varan bir varlık olarak ortaya çıkar. Bir yosun, bir karnabahar ya da çürümüş bir nesne değildir o; öznel olarak kendini yaşayan bir tasarıdır (...) insan nasıl olmayı tasarladıysa öyle olacaktır." ${ }^{14}$ Her bir tasarıda kendimizi seçmekle, tüm insanlığı seçmiş ve beraberinde de “insanı” seçmiş oluruz. Başka bir deyişle her eylemimizde kendimizle birlikte çevremizi de değiştirerek bunu bir görev haline getirmekteyiz.

İnsanın kendi varlığı ve diğer varolanlar arasındaki ilişkiyi anlama çabası aynı zamanda varoluşunu inşa etme süreci, ahlak ve sanat alanı için de geçerlidir. Herhangi bir ahlakın kılavuzluğunda hareket eden birisi, varoluşçu için Hıristiyan umutsuzluğu ve mutsuzluğuna düşmüş olandır. "İnsan kendi kendini oluşturur, o hazır-yapılı bulmaz; o ahlakını seçimiyle, kendi oluşturur ve bir ahlak seçmeden edemez, bu zorunluluğun arkasındaki şey şartların üzerindeki baskısıdır. İnsanı ancak bağlılıklarıyla tanımlanırız." ${ }^{15}$ Sartre’a göre bir dinin öğretilerinin yalnızca bir grubu kapsaması ya da önceden belirlenmiş ahlak ilkelerinin uygulamada olması kabul edilemezdir. Her ahlaki davranış veya seçim tüm insanlığı içermekle birlikte önceden belirlenmiş olandan soyutlanmak durumundadır. Sorun zaten burada Tanrı'nın varlığı veya yokluğu değildir, Tanrı'nın varolan sıfatında olmamasıdır. Sartre'a göre sadece insan varolur ve her şeyin başlatıcısı odur. "Değerler, çimenlere basmayı yasaklayan uyarı levhalarına benzer bin türlü küçük ve gerçek gereklilik gibi yolumun üstüne serpiştirilmişlerdir. [...] Bunun dişında somut olarak çalar saatler, uyarı levhaları, vergi beyannameleri, polis memurları, kısacası içdaralmasına karşı bir sürü korkuluk vardır." ${ }^{16}$ Bunlarla yaşayan insanlar için "başlangıç" söz konusu değildir. İnsanın burada yapması gereken hiçbir şey kalmamıştır. Ancak ne zamanki insanda bulunan özgürlük bilinci, içdaralmasıyla fark edilecek işte o vakit bu duygu, tüm korkulukları hiçleyecektir. Yolumun üzerine önceden bırakılmış bu korkuluklar, tek başıma karar verdiğim her anda birer birer devrilirler. Geriye kalanlar ise doldurulmayı bekleyen levhalardır. İyi davranış ve kötü davranış arasındaki fark nedir, dürüst eylem hangi durumlarda geçerlidir? Artık bunların hiçbirinin yazılı olmadığı bir durumla karşı karşıyayız. Bir varoluşçu için;

"genel bir ablâk yoktur; çünkü size yol gösterecek bir işaret yoktur dünyada. Gelgelelim, katolikler, "Vardır!» diye ayak direrler. Hadi, tutalım ki var böylesi işaretler; var ama onları yorumlayan, taşıdıkları falanca anlamı seçen de biziz yine. Esir düştügüüm günlerdeydi. Illgi çekici bir Cizvit tanımıştım. Papazla arasına katılması şölle olmuştu: Bir sürü bahtsızlı̆ga uğramıştı hayatta. Daha çocukken babası ölmüş, yoksul ve kimsesiz

13 Funda Abalı, Jean-Paul Sartre’ın Tiyatro Yapıtlarında Varoluş̧̧ Felsefe ve Fenomenolojik Sanat Anlayışı, Yayımlanmış Yüksek Lisans Tezi, Dokuz Eylül Üniversitesi, İzmir, 2017, s.144.

14 Funda Abalı, Jean-Paul Sartre’n Tiyatro Yapıtlarında Varoluşçu Felsefe ve Fenomenolojik Sanat Anlayışı, s. 145.

15 T.S. Eliot, Hümanizmin Özü, "Jean-Paul Sartre, Varoluş̧uluk Bir Hümanizmdir” (1946), Çev. Ahmet Aydoğan, İstanbul, İz Yayıncilık, 2002, s.126.

16 Jean-Paul Sartre, Varlık ve Hiçlik (Fenomenolojik Ontoloji Denemesi), Çev. Turhan Ilgaz, Gaye Ç. Eksen, İstanbul, İthaki Yayınları, 2011, s.91. 
kalmıştı. Bunun üzerine bir din okuluna sı̆̆ınmıştı. Yazık ki bu durumu, durmadan başına kakılıyordu çocukcă̆ızın, acındiğı için içeri alındiğı duyuruluyordu kendisine. Bu yüzden, küçüklerin hoşlandiğı o onur yüceltici, okşayzcı hareketleri görmedi hiç. Üstelik on sekizine gelince, başarısızlıkla biten bir aşk serüveni geçirdi. Yirmi ikisinde subaylık sinavin kazanamadı. Önemsiz bir şey belki, ama onun için bardăğ taşıran bir damla oldu bu. Genç adam şöyle dü̧̧ünebilirdi: Tam başarısızliğa uğramıştı, yenilmişti. Işste bu bir işaretti. Ama neyin işareti? Koyu bir üzüntü ya da umutsuzluğa kapılmak işten bile değildi. Öyleyken, delikanl enine boyuna bir güzel düşündü, şuna vardi: Evet, bir işaretti bu. İsaret gösteriyordu ki, dünya işlerinde zaferler kazanacak bir kimse değildi o, böylesi işler için yaratılmamıştı. Dinin, ermişliğin, inancın (imanın) getireceği başarılar için yaratılmışt. Ancak bu yolda zaferler kazanabilirdi. Sonunda, Tanrının bir işareti saydı bunu. Kalktı tarikata girdi, Cizvit oldu. Görüldü̈̆̈̈ üzere, bir işaretin anlamı üzerine karar verirken tek başınadır insan. Nitekim, bunca başarısızlık karşısında delikanlı bir başka karar da verebilirdi: Sözgelimi, devrimci ya da doğramacı olmak isteyebilirdi. İstemediğine göre, işareti yorumlamanın bütün sorumluluğu onundur, yalnızca onun omuzlarındadır." ${ }^{17}$

İnsan bu terkedilmişliğinde, her şeyi yeniden kendisi oluşturacaktır ve bu kez eyleminin nedeni Tanrı veya bir başkası olmadığı için insan bu eyleminden sorumlu tutulacaktır. Sorumluluk ise eyleme doğrudan bağlanmayı gerektirir. Biz kendimizi ve çevremizi anlamlandırırken, tüm davranışlarımızı kendi özgürlüğümüz içinde bağlanmış olarak buluruz. İnsan bu bağlanmaya bir başkasının zorlamasıyla değil bizzat kendi seçimleriyle karar vermiştir.

Saf bir öznelciliği değil de bireyselliği ön plana çıkaran hümanist ateist varoluşçu felsefe anlayışı için benzer şey sanatçı ve onun yapıtları arasındaki ilişki içinde geçerlidir. Ancak Sartre 1947 Yılında Edebiyat Nedir? kitabında edebiyata diğer sanatlardan farklı olarak ek bir ayrıcalık tanındığını söyleyebiliriz. Sartre resim, heykel, mimari gibi plastik sanatları ve müzik sanatını kendi nesnesini yaratılmaları esnasında "düşsel nesneye (imaginary object) ortaya kondukları anda düşsel bir değere sahip olan sanat nesnesine” dönüştükleri için aradığı bağlanma durumunun dışına yerleştirir. Plastik sanatlar ve müzik dışarıda bırakıldıktan sonra Sartre’a göre geriye yalnızca sözcükler kalmaktadır. Sartre şöyle söyler; "burada da bir ayrım yapmak gerekir: imlerin (göstergelerin/signs) egemen olduğu yer düzyazıdır; şiir, resmin, yontunun müziğin yanındadır." ${ }^{18}$ Hiçbir kışkırtma veya çağnıya başvurmadan yapıtlar ortaya çıktıklarında zaten düşsel nesneye dönüşmüşlerdir ve ortaya çıkmaları için fazladan bir çabaya gereksinim duymazlar. Nesneleşmiş olma bir bitmişlik/tamamlanmışlık formu olduğundan Sartre’ın geleceğe doğru aşma, tasarı (proje) olma haline kadar gidemez. Oysaki “yazar, konuşan kimse'dir. O gösterir, ortaya koyar, buyurur, yadsır, çağırır, yalvarır, hakaret eder, inandırır, araya sokuşturur. Bunu boş yere yaptığı zaman ozanlaşmaz.” ${ }^{19}$ Görüleceği gibi, yazar geçmiş ve şimdi arasında mekik dokuyan birisi değil, bizzat mevcut olan, verili olanı aşma yoluna girmiş

17 Jean-Paul Sartre, Varoluş̧uluk, Çev. Asım Bezirci, İstanbul, Say Yayınları, 1985, s.76-77.

18 Jean-Paul Sartre, Edebiyat Nedir?, Çev. Bertan Onaran, İstanbul, Can Yayınları, 2008, s. 18.

19 Sartre, Edebiyat Nedir?, s.27-28. 
ve gelecek yönünde aşma hareketi yapan, gösterdiğini tasarı (proje) olarak sunan kişidir. $\mathrm{Bu}$ özelliğiyle yazar, bir programa/doktrine/reçeteye bağl1lı̆̆ 1 ile değil, kendi söyleyeceği şey ile gelir. Yazar, nesne olarak sözcügü değil bir nesneyi belirten sözcüğü kullanır. Bu şekilde hem kendisini hem de okuru işaret ettiği yere çağırır. "Şimdi artık elimdedir, söylediğim her sözcükte kendimi biraz daha bağlarım dünyaya, ve aynı zamanda daha çok dışına çıkmış olurum, çünkü gelecek yönünde aşıyor olurum onu." 20

"Her resim, her kitap varlı̆ğn bütünlüğ̈̈nün yeniden ele geçirilişidir; her sanat yapıtı bu bütünlüğ̈̈ seyircinin özgürlüğ̈̈ önüne getirir. Çünkü sanatın en son ereğgi de budur: dünyayı olduğg gibi, ama sanki kaynağın insanı özgürlükten alıyormus gibi göstererek yeniden ele geçirmek, yakalamak. Bununla birlikte, yazarın yarattı̆̆g şey ancak seyircinin gözünde nesnel bir gerçeklik kazandiğg için, bu ele geçiriş, bu yakalayış, seyretme -ve özellikle de okuma- töreniyle kutsanır. Az önce ortaya attı̆̆ımız soruya daha iyi karşıllk verecek durumdayzz şimdi: Yazar, aralarındaki karşılıklı istekler yardımıyla varlı̆ğn bütünlü̈̆̈̈ӥ̈ insanoğluna yeniden kazandırsınlar ve evreni yeniden insanlık örtüsüyle kaplasınlar diye öteki insanların özgürlüğ̈̈ne çağrıda bulunur." 21

Başka bir deyişle Sartre’a göre düzyazıdan ayrılan diğer sanat dalları her zaman okuyucu ile aynı ortak suçu paylaşma konusunda istekli olmayabilir. Ancak Sartre ilerleyen sayfalarda Tintoretto'nun Çarmışa Geriliş (The Crucifixion) ${ }^{22}$ resminde Golgotha'nın arkasındaki sarı gögün yırtılışının, bunalımı temsil eden içdaralmasının bizzat kendisi olduğunu söyler. "Resim şimdiki zamanın yalnızca yalın bir betimlemesi olmayıp bu şimdiki zamanın bir gelecek adına yargılanması olduğu; ve yazın, her kitapta bir çağrı bulunduğu için, bu kendi-kendisi-için-varolma daha işin başında bir kendini aşmadır.”23 Böylece sanatçının önceden belirlenmiş bir takım kurallara göre hareket etmeden kendi yaratma ve keşfetme yoluyla yapıtını ortaya çıkarması sadece kendisi için değil tüm insanlık adına yapılmaktadır.

"Herkesin bildiği gibi, onun yapması gereken şey önceden belirlenmiş bir resim değildir; sanatçı kendisini bir resmin kom-pozisyonuna verir ve yapılması gereken resim tam olarak onun yapmış olduğu resimdir. [...] Resmin yarın nasıl bir şey olacağın kimse söyleyemez; hiç kimse yapılıp bitinceye kadar bir resmi yargzlayamaz. Bir sanat eserinin asla sorumsuz olduğunu söyleyemeyiz." ${ }^{24}$

İnsanlık adına verilen bu karar ve yapılan eylem Sartre’a göre ahlak ve sanat alanı için bağlanma (İng. Commitment, Fr. Engagement) olarak tanımlanabilir. "Bağlanma estetik bilinci oluşturan temel bir özelliktir. Nasıl oluyor da bir tiyatro oyunu onu izleyen kimseyi bir duygudan başka

20 Sartre, Edebiyat Nedir?, s.31-32.

21 Sartre, Edebiyat Nedir?, s.67.

22 Şekil: 1

23 Sartre, Edebiyat Nedir?, s.172.

24 T.S. Eliot, Hümanizmin Özü, "Jean-Paul Sartre, Varoluş̧uluk Bir Hümanizmdir” (1946), Çev. Ahmet Aydoğan, İstanbul, İz Yayıncılık, 2002, s.125. 
bir duyguya sürüklüyor? Ya da bir roman onu okuyan kimseyi derinden sarsabiliyor? Bunun nedeni ona inanmak ya da ona bağlanmaktır." 25 Sanatçı, yapıtını oluştururken her eyleminde bir sorumluluk ve bağlanma yaşıyorsa onunla ilgilenen izleyici de aynı şekilde o yapıtın amacını yerine getirmesi için bağlanmayı devam ettirecektir. Sanatçı, toplumun sorunlarını ve ihtiyaçlarını nasıl göz ardı edemiyorsa benzer şey izleyici ve okuyucu içinde geçerli olacaktır. Sartre’a göre "çağ sorumluluk altındadır," ${ }^{26}$ sanatçı da bu sorumluluğa hizmet edecek olandır. İnsan, ilgi ve kaygı duyan bir varolan olmasından dolayı, kimse tarafsız veya sorumsuz davranma lüksüne sahip değildir. Aksine bu lüks insanı, toplum dışına itmekle tehdit eder, oysaki insan diğerleriyle birlikte varolan ve özgürleşendir. Bu nedenle Sartre için sanat kesinlikle sadece sanat için yapılmaz, onun artık toplumsal bir görevi vardır. "Değiştirme kaygısı olmadan özgürlük istemek, güzel bir eser karşısında bir an için kendi özgürlüğünün tadına varmak anlamına gelir. $\mathrm{Bu}$, burjuvaziye karşı çıkarken bir yandan da burjuvazinin çıkarlarına bağlı olmak demektir.” ${ }^{27}$ Sartre, bu nedenle burjuva felsefesinin sadece ilkelerini reddetmekle kalmaz, onların saf sanat, soyut sanat anlayışlarının da geçersizliğini göstermiş olur. Varoluşçuluk, bir burjuva felsefesi olmadığına göre, sanatçı ve toplum birbirine sıkıca bağlanmıştır. Bu her iki tarafı da özgürleştiren bir olanaktır. Sanatçı yazmakla, yapmakla, boyamakla özgürleşirken toplum da öğrendikleriyle dünyayı değiştirme yoluyla özgürleşir.

\section{Sartre'ın Sanat Anlayışı}

Sartre, Edebiyat Nedir? kitabında edebiyatın, diğer sanat dallarına göre bağlanmanın daha çok olduğu bir disiplin olarak tanımlarken, 1963 yılında bu düşüncesinde ısrarlı olduğunu söylemek güç olacaktır, çünkü bu yapıtında sanatın sanat için olma idealini eleştirirken, onun en büyük sorumluluğun toplumsal olduğunu söyler ve bu ifadeler, ilk referans aldığımız kitapla paralellik taşımaktadır. Sartre’ın düzyazı sanatına ilişkin görüşünün yanında plastik sanatlara yönelik düşüncesine geldiğimiz zaman ise Estetik Üzerine Denemeler yapıtında dört sanatçıyla karşılaşırız. Bunlardan ilki, Venedik'te Jacopo Robusti olarak tanınan Tintoretto'dur (1518-1594). Tintoretto, on altıncı yüzyılda Venedik'teki sanatçılar arasında olan kıyasıya bir mücadelenin kurbanı olur. Önce Titian adıyla tanınan Tiziano Vecellio'ın (1488-1576) yanına çırak olarak işe girer ancak orada ustasının kıskançlığı Tintoretto'nun kapı dışarı edilmesine neden olur. Daha sonra Venedik'te para kazanabilmenin tek yolunu bir başkasıyla değil de kendi ailesiyle çalışmakta bulur. Hayatının tümünü bu planı uygulamak üzere değiştirir ve bir aile atölyesinde mücadelesine devam eder. Ne Michelangelo (1475-1564) gibi bir asilzade olarak doğmuştur ne de Raffaello (1483-1520) gibi saraylarda daimi çalışmak için bir anlaşması vardı. Diğerleriyle savaşmanın zorluğunun yanında Tintoretto, kendi özgün sanatını oluşturması, dönemin sanatsal kurallarından çıkıp kendi bilgisini konuşturması ve zanaattan çok sanatsal özellikler barındırmasıyla Sartre’ın bağlı sanat anlayışının en iyi örneklerinin başında gelmektedir. Tintoretto, "Maniyerist akımının

25 Sema Sökmen, Fenomenolojik Ontoloji Temelinde Jean-Paul Sartre’ın Sanat Anlayışı, Yayımlanmış Yüksek Lisans Tezi, Adnan Menderes Üniversitesi, Aydın, 2013, s.108.

26 Jean-Paul Sartre, Estetik Üzerine Denemeler (1963), Çev. Mehmet Yılmaz, Ankara, Doruk Yayınevi, 1998. (Kitabın özgün adı, Situations-IV, İngilizcede, Essay in Aesthetics diye geçmektedir), s.118.

27 Funda Abalı, Jean-Paul Sartre’nn Tiyatro Yapıtlarında Varoluş̧u Felsefe ve Fenomenolojik Sanat Anlayışı, Yayımlanmış Yüksek Lisans Tezi, Dokuz Eylül Üniversitesi, İzmir, 2017, s.163. 
bir temsilcisidir. [...] Üslup ve tarzı ön plana çıkarmakla sanatçının artık zanaatçı olmadığı, bir yaratıcıya dönüştügü sanat anlayışıdır.” ${ }^{28}$ Gözler artık gökyüzünden yeryüzüne doğru çevrilmekle birlikte ışığın yeri de değişmiştir. Kutsalın tuvaldeki yerini ressamların rekabetleri almıştır. Yaratıcı artık Tanrı değil, bizzat ressamın kendisi olmaya başlamıştır. Özellikle resim sanatının büyük bir değişime girdiği bu dönemde sanatçıların eylemleri "artık ruhban sınıfı için yapılmamakta, tüccarların istekleri önemli olmaktadır. Resimde perspektifin kullanılmaya başlamasıyla tuvalden duyuüstü dünyanın kovulması ve dünyanın belirmesi anlamına geliyordu." ${ }^{29}$ Leon Battita Alberti (1404-1472) tarafından perspektifin keşfiyle Tintoretto'nun resimleri Venedik'teki pek çok usta ressamı geride bırakmaya başlamıştır. "Eğer bir insan uzakta kayboluyorsa, bir sis perdesinin örtüştüğü meçhul bir yerde gömülü ise, ya da bir gaz lambasının sisiyle karartılıyorsa, bu kesinlikle tesadüfen değildir." 30 "Sahip olduğu şey insan hakkında bir görüş değil, insan bedeni konusunda edinilmiş bilgisiydi." ${ }^{1}$ Özellikle Aziz Marcus’un Mucizesi32 (1562) perspektifin yoğun olarak kullanılmasıyla resim sadece Tanrı’nın keşfi veya öğretileri değil insanın kendisinden de bir şeyler bulabileceği (bir gölge ve uzaklık-yakınlık) bir bulmacaya dönüşmüştür. "Yaptığı resim çağdaşlarını hayretler içinde bırakır, ama aynı zamanda onları zıvanadan da çıkarır. Ateşli düşmanlar, hiç de heyecanlı olmayan dostlar edinir."33 Tintoretto, kendi varolmasını diğerlerine kabul ettirmek için bunu yapmak zorunda kalmıştır. Sartre sanatçının her eyleminin bağlanmaya dönüşmesine vurgu yaptığ 1 yerde Tintoretto'da artık ölünceye kadar perspektifteki her firçasında bir haydut olarak anılır. Onlara göre kimse bu kadar ileriye gitmemişti. Sartre’a göre dehasının farkında olan ama değerini bilmeyen Tintoretto'nun tek amacı boyamak ve satmak üzerine kurulmuştur. Hatta dönemin ünlü ressamlarının tablolarını dahi en ucuz fiyatlara bitirerek müşterilerine teslim eder. "Gerçeğe uygun ve alışıldık bir şey istiyorsunuz, öyle mi? Sorun değil hallederiz,"34 diyerek pazara dizilen ve müşterileri tarafından alınmayı beklenen birer sebze ve meyve olarak diğer ressamlarla kuyrukta bekliyordu. Tintoretto'yu, sanatın bu kıyasıya savaşına rağmen sadece geçinebilmek için daha fazla tablo yapma hırsı onu doyumsuz ve sabırsız kılmıştır. "Çılgınca bir gurur, ahmakça bir alçak gönüllülük, prangalı bir ihtiras, başıboş bir ürkeklik, insafsız azarlar, peşini bırakmayan kötü talih, başarı dürtüsü ve başarısızlığın kamçı darbeleri..."35 Oysa Sartre’a göre bir varoluşçu, kendi tutkusunun peşinden gitmez, insanın bir rüzgâra kapılıp sürüklenmesini reddeder. Tutkusu onu değil, yalnızca o, tutkuyu yönlendirebilirdi. İnsanın dünyaya terkedildiğinin bir örneği olan Tintoretto Tanrı'nın olmadığı, kutsalın kaybolduğu yerde tek başına kalmıştır. Boyama tutkusuyla bu yalnızlığına bir yön vererek Tanrı için değil Venedik uğruna kendini feda etmiştir. Diğer soylu sanatçılar istedikleri zaman boyarken, Tintoretto filozofça tutkuyla gece gündüz boyamak zorundaydı. Tintoretto, dehasını karanlığın eline bırakmadan sanatın artık kendine yeni amaçlar ve anlamlar içerdiğinin farkındaydı. Bırakın Tanrı ve İsa’nın imgelerini

28 Sema Sökmen, Fenomenolojik Ontoloji Temelinde Jean-Paul Sartre’ın Sanat Anlayışı, Yayımlanmış Yüksek Lisans Tezi, Adnan Menderes Üniversitesi, Aydın, 2013, s.112.

29 Sökmen, Fenomenolojik Ontoloji Temelinde Jean-Paul Sartre’in Sanat Anlayısıı, s. 118-119.

30 Jean- Paul Sartre, Estetik Üzerine Denemeler (1963), Çev. Mehmet Yılmaz, Ankara, Doruk Yayınevi, 1998, s.56.

31 Alberto Giacometti, Yazılar (2004), Çev. Aykut Derman, İstanbul, Yapı Kredi Yayınları, 2015, s.159.

32 Şekil:2

33 Jean- Paul Sartre, Estetik Üzerine Denemeler (1963), Çev. Mehmet Yılmaz, Ankara, Doruk Yayınevi, 1998, s.6.

34 Sartre, Estetik Üzerine Denemeler (1963), s.11.

35 Sartre, Estetik Üzerine Denemeler (1963), s.14. 
Venedik' in en büyük ressamlarının bile imgeleri Tintoretto'yla birlikte kopyalanabilir, hatta daha iyisi yapılabilirdi. Tuvalin konusu "ressamların imgeleriyle" 36 dolmaya başlamıştı. "Tanrı insan ruhundan çıkarılıp firara zorlanmıştır: Mutlak, yokluk demektir artık. Yaratmak için daha çok erken, yansıtmak için ise çok geçtir. Ressam cehennemdir, anlayacağınız." ${ }^{37}$ Tintoretto ve pek çok ressamla birlikte deha nereye oturacağına henüz karar verememiştir. Venedik’te bu yaratıcı güç, şimdilik kendini pazarlarda satmaktadır. Hiçliğin varolan üzerinde bir kurtçuk olarak kendini var etmesine benzer biçimde deha da şimdiden sanatçıya musallat olmuştur. Ressamların bu yeni tasarımlama güçleriyle tam olarak ne yapacaklarına, nasıl kullanacaklarına karar verememeleri, "resmi tasmasız bir köpek" ${ }^{38}$ haline sokmuştur. "Tintoretto'nun sanat yapıtlarında figürler huzursuzdur. Onun dünyası başarısızlık ve kaygıyla doludur. Eski huzurlu, düzenli, başarı dolu, kutsanmış dünya kaybolmuştur." ${ }^{39}$ Her şeye rağmen Sartre için Tintoretto'nun önemi vazgeçilemezdir çünkü sanatın tam olarak seküler olma yolunda Tintoretto kendini, dehayı ve ailesini çok sevdiği Venedik'e adamıştır. Sanatın bu toplumsal görevi ve sanatçının hayatının sonuna kadar bir davaya dönüşen bu tutkusu Sartre’a göre din uğruna kurban edilenlere karşı bir başkaldırıdır. Özellikle Leonardo da Vinci (1452-1519) tarafından yapılan Son Akşam Yemeği $(1495)^{40}$ ve Tintoretto'nun Son Akşam Yemeği (1564) ${ }^{41}$ tabloları arasındaki fark, sanatın bir takım kutsanmış değerlerden arındığını ve yeni bir tarzın başlangıcını göstermektedir.

Bir varoluşçu için Venedik ressamlarını önemli kılan bir başka özellik ise tablolarında "bireyselliğin yasak" ${ }^{2}$ olmasıdır. Sartre’a göre, bir hümanist ateist varoluşçu her daim öznel olandan başlamalıdır ancak ne zaman ki bu özellik, saf bireyselliğe dönüşür işte o vakit sorun yaşanır, çünkü dünya içinde sadece ben veya öteki bırakılmadı. Birlikte bu duruma maruz kaldığımıza göre varoluşçuluğun öznelciliği, tüm insanlığı kapsayacak şekilde genişletilmelidir. Tam olarak insan durumunun evrenselliği içerisindeyiz. Venedik halkı neyi sipariş ettiyse onu yapan bir ressam için bireysellik zaten para kazandırmayan bir şey haline gelmiştir. Venedik'te yoksul bir ressam olan Tintoretto, hem sanat alanına bir eylem koyarak özgünlügünü gösterir hem de toplumun ihtiyacı olan tüm şeyleri tuvaline yerleştirmeyi arzular. Böylece Sartre için Tintoretto varolma tarzını değiştirmeyi başarmış bir sanatçı olarak sıçramanın bizzat örneğini bize sergilemiştir, çünkü sanatçı toplumun belli ölçütlerine uyan, ortak değer yargılarıyla belirlenmiş olandır. Tintoretto, tablolarında kutsallıkla ilgili sıfatları kullanmasına rağmen bunu kendi imgeselliğinde aşmayı başarır. Sartre’a göre bir sanatçının boyadıkları hemen şimdi etkili olacak şeylerdir. Hem sanatçı hem de izleyici bu çağrının sesini duymazdan gelemez, olur da bunu yaptığını iddia ederse, o yalnızca kendini aldatır. Böylelikle sanat şimdiden sanatçı ve toplum arasında tam bir bağlanmanın olduğu ve birbirini karşılıklı özgürleştiren bir özellik barındırdığı yerdedir. Ne Tintoretto Venedik'e ne de Venedik Tintoretto’ya yabancı kalmıştır.

36 Sartre, Estetik Üzerine Denemeler (1963), s.45.

37 Sartre, Estetik Üzerine Denemeler (1963), s.47.

38 Sartre, Estetik Üzerine Denemeler (1963), s.48.

39 Sema Sökmen, Fenomenolojik Ontoloji Temelinde Jean-Paul Sartre’ın Sanat Anlayışı, Yayımlanmış Yüksek Lisans Tezi, Adnan Menderes Üniversitesi, Aydın, 2013, s.114.

40 Şekil:3

41 Şekil:4

42 Jean-Paul Sartre, Estetik Üzerine Denemeler (1963), Çev. Mehmet Yılmaz, Ankara, Doruk Yayınevi, 1998, s.60. 
Dahası onun tablolarını görmek isteyen izleyicilerin Venedik'e gitmekten başka çaresi yoktur. Maskelemenin nesnesi olan gölge bu tamlıkta erimiştir. Venedik, onun çalışmalarına sonsuza kadar sahip çıkmakla Tintoretto’ya bağlanmıştır.

Sartre’a göre sanatçının her eyleminin gerçeği yansıtmak dışında onu başarısızlığa iten ve yine de içindeki toplumu bu başarısızlık içinde yansıtmayı başarabilmiş bir sanatçı vardır: Alberto Giacometti (1901-1966). Şimdiye kadar pek çok heykeltıraş, insanı bir taş, nesne veya anatomik özellikleriyle sergilemişken Giacometti ilk kez onun bir varlık değil varolan olduğunu, varoluşsal özellikler barındırdığını kesitler halinde sunar. Yaşamın hareketliliğini takip edebilmek için heykellerinde bitmemişliği savunan Giacometti, mutluluğun bu eksiklikte yattığını söyler. Çalışmasının başına her zaman gerçeği yansıtmak için oturan Giacometti hiçbir zaman yapıtını birebir aynısı olarak yapamamıştır. Oysa Sartre’a göre "olumsuzlamalar [...] varlığın içine dağılmışlardır, varlık tarafından desteklenirler ve gerçekliğin koşullarıdırlar.” ${ }^{43}$ Giacometti'nin model olarak kardeşi Diego'yu kullanmasına rağmen heykellerin ona benzememesi Sartre için Diego'yu destekleyen tek gerçekliktir. Giacometti'yi önemli kılan bir diğer şey ise heykellerinin gerçek boyutlarda olmamasıdır. Yaptığı heykellerinin hiçbirinin gerçek boyutlarda ve görünümlerde olmaması Giacometti için “olumsuz birim” olarak görülür, çünkü insan bedenindeki her bir ayrıntı Giacometti'ye göre her zaman kafa karıştırıcıydı. Bu nedenle mümkün olduğunca uzaklaşmak istedi ancak bu durum karşısındakini kaybetmesine neden oldu. Giacometti'nin heykelleri ve gerçeklikleri arasındaki mesafe Sartre için en önemli özelliklerden biridir. Mesafe ve gerçeklik arasındaki olumsuzlama, "birliği gerçekleştiren harçtır. O iki noktayı bağlayan ve onları mesafenin ayrıştırılamaz birliği olarak görüye sunan dolaysız bir münasebeti kesin bir biçimde tanımlar.” ${ }^{44}$ Mesafelerini her fırsatta koruyan heykeller, hiçliğin ve varlığın ortasına bırakılmışlardır. Giacometti ise bu uzaklığı boşlukla tamamlama ve gerçekliği elde etme peşindedir. İzleyicisini karşısına alan bir heykel, aradaki mesafenin kaybolmasına izin vermez. Sanatçı için bu uzaklık aşılamaz olandır. "Çünkü boşluk her zaman varlıktan önce gelir. Varlığın onun içinde barınabilmesinin tek koşulu ise etrafının, boşluğun zarlarıyla çevrilmesidir." ${ }^{45}$ Başarısızlığın bir sanatçı tarafından maskelenmeden doğrudan sergilendiği bu heykeller, tıpkı onları yapan ellerin geri çekilmenin sonucudur. Sartre’a göre Giacometti, birbirini kaybeden, yalnızlaşan, umudunu yitirmiş kalabalıklar üzerine çalışır. İnsanın, kalabalıklar içinde yalnız olmadığını, diğerleriyle var olduğunu boşluklarla anlatmaya çalışan Giacometti, oldukça kolay parçalanabilen alçılardan insanın tam bir doluluk olamayacağını göstermeye çalışır. Her bir varolanın kendi boşluğunu, olumsuzlamasını veya hiçliğini barındırması sanatçı için insanı tamamlanmışlıktan alıkoyar, çünkü ona göre varolan sürekli olmaktadır. Giacometti şöyle söyler; "1920'de Roma'daydım, tüm kış boyunca bir dostumu model olarak kullandım, belki altı ay boyunca ve sonra, yaptığım başı, oradan ayrılırken çöp tenekesine attım. Bir başı bütünüyle yakalamak olanaksızdı." ${ }^{26}$ Bu yüzden her heykel Rönesans ressamı Michelangeo'nun

43 Jean-Paul Sartre, Varlık ve Hiçlik (Fenomenolojik Ontoloji Denemesi), Çev. Turhan Ilgaz, Gaye Ç. Eksen, İstanbul, İthaki Yayınları, 2011, s.71.

44 Sartre, Varlık ve Hiçlik (Fenomenolojik Ontoloji Denemesi), s.70.

45 Jean-Paul Sartre, Estetik Üzerine Denemeler (1963), Çev. Mehmet Yılmaz, Ankara, Doruk Yayınevi, 1998, s.69.

46 Alberto Giacometti, Yazılar (2004), Çev. Aykut Derman, İstanbul, Yapı Kredi Yayınları, 2015, s.203. 
Musa Heykeli ndeki $(1513)^{47}$ gibi işte budur, konus, kalk gidelim gibi ifadelerden uzak kalacaktır. Bitmişlik insanı hiçbir şeyin başlangıcı yapmaz, başkalarının değerleriyle yaşamaya alışmış birisi, başkalarının kararını uygulamak zorundadır. Oysa hümanist ateist varoluşçu için Giacometti, insanı hep bir başlangıca götürür. Modern uygarlığın dayatmalarından kendini oldukça uzaklaştıran Giacometti, ilerlemenin gücüne inanmaz.

"Desenleri bir kez daha, daha büyük kararlllıkla inceliyor. Her birinde bir başlangıç var! [...] Kâğıtları toplayıp ters tarafları üste gelecek şekilde kenara koyuyor. Bu yaz buraya yine gelmeye niyetiniz var mı? Varsa, sizin portrenizi yapacağım. Firça ile kendimi kalemle olduğundan daha rahat hissediyorum. Göreceksiniz!” 48

"Her resmi eski bir metafizik soruyu gündeme getirir: Bir şey yok değil de niçin vardır? $\mathrm{Bu}$ inatçı, sorgulanamaz ve aşırı derecede düşsel olan şey nedir.” ${ }^{49}$ Fenomenolojik ontoloji denemesinin, metafizik bir varlık sorgulaması olması nedeniyle Sartre ve Giacometti arasındaki bu yakınlık, insanı bir varolan olarak anlamada yardım etmektedir. Heykeller ve izleyiciler arasına yerleşen mesafe Giacometti için insana yapışmış kalmış olan boşluğun ifadesidir. Boşluktan sıyrılamamanın yarattığı şey bir eylemsizlik olsa dahi insana göre bu karşısında duran bir seçimdir. Dahası bu boşluğun yok sayılması, varolanları bir tamlık içinde görme arzusu ne bir varoluşçu için ne de Giacometti için kabul edilebilirdir. İnsan, bu boşluğun içine saplanmıştır. Size doğru durmadan yürüdüğünü hissettiğiniz heykeller, bir bataklık içinde sanatçı tarafından bir aktör konumundadır. Özellikle Kalabalık Kompozisyon'a (1950) ${ }^{50}$ baktığımızda daimi bir eylem alanı içinde olan insanlarla karşılaşırız. Bir an önce bu kalabalığın nereye gittiğini öğrenmek ve yapmakta olduklarını bilme merakı uyanır. Heykeldeki her bir yüzde, öteki olmadan varoluşu başarısızlıklarla sonuçlanacakmışçasına bir şey belirir, çünkü Giacometti için "bu yüz çevresindeki öteki varlıklara dokunabilen tek bir varlık tarafından doldurulmalıydı." ${ }^{1}$ Her bir heykelde kendimizden özellikler bulabileceğimiz bu sanat yapıtında, sanatçı ve izleyici aynı suça ortak olmuşlardır. "Bizler onun kurbanları ve suç ortaklarıyız," ${ }^{22}$ karşılıklı bağlanma ve sorumluluk, her iki tarafı da ortak suça dâhil eder, çünkü sanat yapıtı hem Sartre hem de Giacometti'ye göre kendimiz ve çevremizi değiştirmek için bir eylem ortaya koyar. Toplumun tüm sorumluluklarını omuzlarında taşıyan sanatçı, sadece kendisinden değil herkesten sorumludur. Bu yüzden Sartre için "sanat sanat içindir" ifadesi kabul edilemezdir. Başımıza gelen her şey yine bizim yaptığımız eylemlerden dolayı gelmiştir. Sanatçı eylemlerin nedenlerini yok sayıp sırf ince beğeniyi geliştirmek için tuvalinin başına oturmamalıdır. Bir varoluşçu şunu der bu konuda: "Korkak kendi kendini korkak yapar, kahraman ise kendi kendini kahraman. Korkak ya da kahraman olmak insanın elindedir. [...] Genel bir bağlanıştır burada önemli olan; yoksa, sizi toptan bağlayan özel bir durum ya da özel bir eylem değil!" 53 Sanatçı ve izleyici arasındaki bu karşılıklı

47 Şekil:5

48 Giacometti, Yazilar (2004), s.169.

49 Jean-Paul Sartre, Estetik Üzerine Denemeler (1963), Çev. Mehmet Yılmaz, Ankara, Doruk Yayınevi, 1998 , s.72.

50 Şekil:6

51 Sartre, Estetik Üzerine Denemeler (1963), s. 84.

52 Sartre, Estetik Üzerine Denemeler (1963), s.80.

53 Jean-Paul Sartre, Varoluşşuluk, Çev. Asım Bezirci, İstanbul, Say Yayınları, 1985, s.83. 
bağlanma Sartre’a göre "bir kabullenme değildir. Özgürlüğümüzün sonuçlarının mantıksal hak talebidir. [Bu yüzdendir ki] Varlığa belirdiğim andan itibaren dünyanın ağırlığını, hiçbir şeyin ve hiç kimsenin hafifletemeyeceği ölçüde tek başıma taşıyorum." ${ }^{54}$ Dahası ne sanatçı ne de izleyici denizin üzerindeki bir tahta parçasıymışçasına akıntının sürüklediği yöne doğru gidemez. Dünya içine bırakılmışlıkları, onları boya fırçasını eline almaktan, sergi salonuna girip izlemeye koyulana kadar sorumlulukla bağlar. Bu nedenle Giacometti'nin amacı "gerçek insanların varoluşları yoluyla, içimizdeki hisler ve davranış tarzları uyandıran imgeler üretmektir." 55 Sartre’a göre uydurulmuş imgeler ve eyleme neden olan imgeler arasında fark vardır. İlki sıradan bir korku nesnenin ortadan yok olmasıyla ilişkilendirilebilir. Diğeri ise insanı saran derin bir içdaralması olarak görülür. Ne yaparsak yapalım peşimizi bırakmayan bu duygu âdeta bize angaje olmuştur. Sanatçı kendi imgesini yaratırken, onu toplumla ilişkilendirmekle birlikte, hiçbir zaman tam olarak ortaya koyamaz, çünkü hümanist ateist varoluşçu için tamamlanmış, bitmiş bir şey yoktur. Sanatçı her zaman istediğinin daha azını veya eksiğini verecektir. Sonsuz olan görünmelerin kendilerini sürekli olarak kesitler halinde sunması onun tüm görünmesini yakalayabilmenin olanaksızlı̆̆ını gösterir, aksi halde Giacometti’nin yaratıcılığını, sadece yapıtlarıyla sınırlandırıp başka bir özelliğinin olduğu söylenmeyecektir. Oysaki Giacometti, hem sanat yapıtlarında hem de onlardaki görünümlerden daha fazlasıdır, çünkü varlık alanında sadece bir doluluk yok aynı zamanda buna hiçlikte eşlik eder. Hiçliğin eylem alanına bu girişi, galerideki herkes için "Giacometti burada şunu değil de acaba bunu da anlatmak istemiş olabilir" tercihini sunmaktadır. Ötekisi salona girer girmez Diego’nun (1959) gözlerinin açık mı kapalı mı olduğuna karar vermekle eş değerdir. Hatta tablolar arasında Diego'yu hemen tanımakta buna dâhil edilebilir. Başka bir deyişle Giacometti'nin Sartre'ın yakın dostu olmasının nedeni her seferinde resmi, heykeli tam kavrayacakken, aniden tüm görüntünün yok olmasıdır. Her zaman bekleneni sunma konusunda verilmiş sözü olmayan Giacometti’nin bu tavrı Sartre tarafından aşırı bir kararlılık olarak adlandırılır. Sanatçı doğada gördüklerini kendi bütünlükleri içinde sergilerken "yaratım hiçbir zaman kesinleşmiş, sonlanmış değildir. Her zaman değişebilirmiş sallantısında görünür. Bir ressam, resmine hiçbir zaman bitmiş gözüyle bakamaz." 56 Sonsuzluk endişesi yaşayan Giacometti, insan varoluşunu sergileme çabasında tek yapabildiği şey figürlerini uzatmaktır. Pek çokları tarafından bu davranış, kutsal özellikler barındırsa da sanatçı için varoluşu bir anlık dahi kavratabilme gayretidir. Her karşılaşmada varlığın gizlerini bulup çıkarma sorumluluğumuz Giacometti'nin eksik kalan heykellerine benzer olarak tamamlanmadan kalacaktır. "Bazıları bir hayli iyi ama yine de tam istediğim gibi değiller." ${ }^{57}$

54 Jean-Paul Sartre, Varlık ve Hiçlik (Fenomenolojik Ontoloji Denemesi), Çev. Turhan Ilgaz, Gaye Ç. Eksen, İstanbul, İthaki Yayınları, 2011, s.688-690.

55 Jean-Paul Sartre, Estetik Üzerine Denemeler (1963), Çev. Mehmet Yılmaz, Ankara, Doruk Yayınevi, 1998, s.81.

56 Sartre, Estetik Üzerine Denemeler (1963), s. 94.

57 Sartre, Estetik Üzerine Denemeler (1963), s.86. 
Hümanist ateist varoluşçu Sartre'a göre soyut sanat anlayış1 ${ }^{58}$ izleyicisinde sadece ince beğeniler oluştururken, sanat yapıtı ve seyirci arasında yönlendirici bir eyleme bağlanmayı engeller. Aldığı haz veya hazsızlık ne onu ne de başkasını bir eyleme yönlendirir. Aynı sanat yapıtının tekrar karşına geçmek seyircinin aklından dahi geçmez. Sartre, bu tarz bir sanat anlayışını reddetmenin yanında "sanat sanat içindir" ilkesinin en popüler olduğu dönemde dahi kendi özgünlügünü koruyabilmiş ve toplumsal görevini yerine getirmeyi büyük bir sorumluluk edinmiş olan doğa araştırmacısı Robert Lapoujade’i (1921-1993) örnek gösterir. "Kimse sanat olsun diye resim yapmaz, yalnızca yapar. Lapoujade’ in çalışma tarzı bunun iyi bir kanıtıdır, çünkü o güzellik olsun diye boyamaz." 59 "Lapoujade tuvalinin her santimetrekaresini güzelliklerle doldurma beklentisiyle boyamaz. Yaptığı şey, sanatın özünden kaynaklanan konularını, amaçlarını, kafasını meşgul eden düşüncelerini ve kendi motiflerini tuvaline yerleştirmekten ibaret." ${ }^{60}$ Sartre’a göre zaten şimdiye kadar sanatçılar ya sırf güzellik olsun diye ya da ahlaki değerleri iletmek amacıyla yaratıcı veya geleneksel imgelerini sergilemişlerdir. Oysa artık sanat, tüm bunlardan ayrılarak ihanet ettiği topluma geri dönmelidir. Bu nedenle Lapoujade, topluma karşı sanatçının sorumluluğu olan eyleme geçirme duygusunu tekrardan gündeme getirir. Yalnızca bu yolla Sartre’a göre izleyici, sanat yapıtının karşısına bir kez daha geçme fırsatı elde edecektir. Lapoujade, edindiği bu amacı gerçekleştirmek için öncelikle figüratif resmin iki önemli ismi olan Francisco Goya (17461828) ve Pablo Picasso’yu (1881-1973) başarılı bulmasına rağmen onların eyleme yönlendirme konusunda yeterince net olmadıklarını söyler, çünkü şiddeti yansıtma konusunda resmi bulmacaya dönüştüren bu sanatçıların, toplumsal olmaktan çok kendi varoluşsal sorunlarına eğildiklerini söyler. Lapoujade ise figüratif ve non-figüratif sanatın gerildiği noktada yer alır. Özellikle $\dot{I}_{s}$ kence $\left(F r\right.$. La Torture) ${ }^{61}$ (1968) resminin bu krizi barındırdığını söyleyebiliriz, ancak Lapoujade, Sartre’a göre resme yeni bir kişilik vererek yıllar içinde kendi özgünlüğünde "bizim, dünyayı yeniden ele geçirmemizi istediği bir yolu seçti." ${ }^{2}$ Sartre "insanlarla ve onların acılarıyla ilgilendiğimizde, dehşetin ne betimine ne de debbede [İng. Majesty] içinde kaydedilmesine razı oluruz" ${ }^{63}$ diyerek gerçekliği tüm çıplaklığıyla sergileyen Lapoujade’in bu betimlemede pek de payı olmadığını ekler. Bu nedenle Lapoujade için resim sanatı, doğrudan eylemle ilişkili olmalıdır. Eyleme yönlendiren sanat ise tüm maskelerden arınarak tıpkı Lapoujade’ in Aynalı Çift $(1968)^{64}$ tablosunda, iletmek istediği şeyi çıplak bir şekilde tuval üzerine firlatır. Böylelikle sanatın kendi sorunlarını bir tarafa bırakarak herkesin yaşadığı ama kimselerin görmediği şeyleri tuvaline dökerek topluma olan sorumluluğu yerine getirmeye çalışır. Ölü doğmuş bir mucizeye karşılık,

58 Soyut Sanat, gerçek dünyada ve doğada var olan nesneleri, varlıkları çizmek-betimlemek yerine renkleri ve biçimleri kullanarak, temsili olmayan ve kişiye bağlı olarak yapılan sanata soyut sanat denir. Temsilci akımları: Ekspresyonizm (Edvard Munch), Fovizm (Henri Matisse), Post Ekspresyonizm (Paul Cézanne, Van Gogh), Kübizm (Pablo Picasso). https://www.cevapbizde.com/1350/soyut-sanat-nedir-soyut-sanat-akimi-nedir-soyut-sanat-ozellikleri-nelerdir-soyutsanat-akimi-sanatcilari-temsilcileri-kimlerdir 30.10.2019.

59 Sema Sökmen, Fenomenolojik Ontoloji Temelinde Jean-Paul Sartre’ın Sanat Anlayışı, Yayımlanmış Yüksek Lisans Tezi, Adnan Menderes Üniversitesi, Aydın, 2013, s.121.

60 Jean-Paul Sartre, Estetik Üzerine Denemeler (1963), Çev. Mehmet Yılmaz, Ankara, Doruk Yayınevi, 1998, s.101.

61 Şekil:7

62 Sartre, Estetik Üzerine Denemeler (1963), s.106.

63 Sartre, Estetik Üzerine Denemeler (1963), s.105.

64 Şekil:8 
sorumluluk almakla, dehasını, kendi varoluşuyla birlikte tüm insanlığın buna dâhil olduğu yaşamsal bir mucizeye dönüştürür. "Deyim yerindeyse saldırır tuvale. Sonra da, bu kez tuvalin bizi çarpması için çekilir aradan. Tuvalle mücadele etmesi, resim yapması demektir. En sonunda varoluş, sanatçının bizzat kendisi olarak görünür tuvalde. Sanatçı eserine saldırgan bir eylem bütünlügü sokmuştur." ${ }^{65}$ Başka bir deyişle Lapoujade’in resimlerinde güzellik, yalnız güzellik olsun diye üretilmez, tuvaldeki eylemler, güzelliğin temelini oluşturur. Özel ayrıcalıklar peşinde koşmayı bırakan bu sanatçı, yaratıcılığını Giacometti gibi, birbirinden ürküp kaçan kalabalıkları bir araya getirmekle sadece o ana hitap etmekle kalmaz, evrensel özellikleri de yansıtmayı başarır. Fırçasını her eline aldığında yeni bir eylem yaratarak, iletmek istediği şeyi boyalarının renkleriyle izleyicisine sezdirir. Anlam bu kez sanatın malzemeleriyle aktarılır. Sartre’a göre sözün yetersiz kaldığı yerde bu yöntemle çağına bağlılığını ifade eden Lapoujade resimlerinde daima şu mesajı verir: "Ben bir ressamım; dünyanın ileri gelen büyük adamları, ben size aitim; ve her zaman, yönettiğiniz bu insan yığınının yüzeyselliğini ve tenezzül edip beni onlardan kurtarmanızı görselleştiriyorum" ${ }^{66}$ demektedir.

Sartre, sanat yapıtının, yaratıcısının imgelerini yansıtmaktan öte sadece bir analogon yoluyla aracılık yaparak sorumlu olduğu şeyi ifade etme konusunda en iyi şeyin devinimli heykeller olduğunu söyler. Eylemin, doğadan ve matematiğin kurallarından ilham alınarak doğrudan harekete geçirici özelliğini keşfeden sanatçı Alexander Calder (1898-1976) hareketi sanatın içine yerleştirmiştir. Sartre’a göre bu sanatçı, her açıdan farklı malzemelerle yapıtını iletmek istediği şeye daha çok yoğunlaştırır, çünkü kaliteli veya ağır malzemelerden öte daha yapay şeyleri tercih ederek anlamın değişir olma özelliğini saklamaktadır. Giacometti veya Calder’in bu tarz ürünler seçmeleri Sartre’a göre boşuna değildir. Alçının veya teneke parçasının bozulabilme olasılığının daha fazla olması onları tek yanlı bir bakış açısından uzaklaştırır. Sartre’a göre başka bir seçeneğin de önümüzde bulunma olasılığı göz önüne alarak sanatçı her firsatta sorumlu olduğu çağa göre edindiği araçların değişebilirliğini bilmelidir. Bunun bilincinde olan Calder, doğayı ve matematiksel hesaplamaları referans alarak hareketi göstermeye çalışır. Özellikle Küçük Örümcek $(1939)^{67}$ ve diğer pek çok çalışmasında izleyicisini de oyuna dâhil eden şeylerle karşılaşırız. Genelde beklemekte olan bir heykele yaklaştığınızda, onun etrafında dolaşarak tam bir bütünlügü görme imkânı sunulur ancak Calder’in devinimli heykellerinde seyircisinin nefesi veya rüzgârıyla dahi harekete çeken çalışmalar insanı eyleme yönlendirerek bütünü görmeyi engellemektedir. Sözün yerine geçen hareketli nesneler, Calder'in imgelerini tıpkı bir derenin akıntısı gibi verir. Bu yüzden çalışma, sanatçının atölyesinde tamamlanmış dahi olsa hiçbir zaman bütünlüğe erişemeyecektir. "Tereddütleri, uyanıklıkları, sanki el yordamı ile bir şey aramaları, aradıklarını bulamamaları, ani kararları ve özellikle de muhteşem bir kuğunun asaletli tavırları, canlılık ve cansızlığın ortasında bir yerde, Calder'ın heykellerini garip birer yaratık yapar çıkar." ${ }^{68}$

65 Sartre, Estetik Üzerine Denemeler (1963), s.115.

66 Sartre, Estetik Üzerine Denemeler (1963), s.118.

67 Şekil:9

68 Sartre, Estetik Üzerine Denemeler (1963), s.129. 


\section{Sonuç}

Sartre edebiyatı diğer sanat alanlarından düşsel nesnenin bizzat yaratma edimi tarafından ortaya çıkmasına dayandığı için ayırırken, diğer yönden hem yazarın hem de sanatçının görevinin okuyucu ve izleyicisine çağrıda bulunması gerektiği konusunda ssrar eder. Bu çağrı tüm sanat dalları için özgürlüğe yöneliktir. Özgürlüğe ilişkin bu çağrı sorumluluk bilincinden bağımsız düşünülmemelidir. Aynı zamanda bu çağrı, bağlanma durumunun ortaya çıkaran özgürlüğü tanımıdır. Bu sayede estetik bilinç, bağlanma yoluyla yemin ederek inanmayı ortaya çıkarır. Bu inanmayı seçmek, hiç durmadan her bilinçte yenilenen bir seçmedir.

Sartre'ın sanat anlayışı içinde Tintoretto, Giacometti, Lapoujade ve Calder, insanın eylem gücünü arttıran sanatçılar, varoluşları özlerinden önce gelmiş olan ve tüm yaşamı boyunca da özünü tamamlamaya çalışan kimselerdi. Sartre’a göre kendisini Venedik'e kurban eden Tintoretto, yaşamının son saatlerine kadar heykellerini tamamlamaya çalışan ve hep bir eksiklik hisseden Giacometti, soyut sanat ve figüratif sanat arasında sıkışmış kalmış ancak oradan çıkmayı başaran Lapoujade son olarak da eylemin, izleyici ve yapıtın bir araya gelmesiyle sağlanacağını vurgulayan Calder, neyim, kimim? sorularını cevaplayamamışlardır. Bu sanatçıları bir araya getiren şey ise şimdide olan şeyin keşfidir. "İçinde bulunduğu anı kaçırmaması gerektiğini fark ederler. Eylemleri uzun vadede gelecek için fayda sağlayacak şeyler değil, hemen şimdi için etkili olacak girişimlerdir." ${ }^{99}$ Sanatçıyı "budur" ifadesiyle gösterdiğimizde içdaralması hep belirir, çünkü Sartre’a göre terkedilmişlik dünyasına angaje olan insan, varoluşunu kendisine musallat olan hiçlik ve olumsuzlamalarla gerçekleştirir. Bu yüzden bir tamamlanma yaşandığını düşündüğümüz anda başka bir seçenek içdaralmasıyla çıkagelir. Başka bir deyişle önemli olan özünü gerçekleştirmek veya en iyi sanat yapıtını ortaya koymak değil, değerler dünyasının işaretlerinden koparak kendi yolumuzun levhalarını yerleştirmektir. Burada kendimize eylem ve özgürlüğü temel alarak, kendi seçimlerimizin nedeni olmalıyız. Bunu gerçekleştirme amacıyla sanatsal yapıtlar ortaya koyan sanatçılar Sartre’a göre kendi içinin sorumluluğunu, yaşadıkları tüm dünyaya yaymışlardır. "Bu kişilerin ne vicdan azabı, ne pişmanlığı, ne de mazereti vardır; o artık, kendi kendisini bütünüyle keşfeden ve varlığı bizatihi bu keşifte yatan özgürlükten başka bir şey değildir." ${ }^{70}$ Bu sanatçıların tek endişeleri, hatasız bir bütünlükte bitiremedikleri çalışmalardır. Yine de yapıtın kesik görünümlerine rağmen sanatçılar, tüm insanlığa eyleme geçmesi için çağrıda bulunmuşlardır. "O halde, Sartre'dan edinebileceğimiz öneri şudur: Eylemlerde bulunun! Fakat eylemlerinizden sorumlu olduğunuzu unutmayın. Eylemlerinizi eleştirin ve sonra daha başka eylemlerde bulunun."71

69 Funda Abalı, Jean-Paul Sartre’ın Tiyatro Yapıtlarında Varoluş̧u Felsefe ve Fenomenolojik Sanat Anlayı̧ıı, Yayımlanmış Yüksek Lisans Tezi, Dokuz Eylül Üniversitesi, İzmir, 2017, s.172.

70 Jean-Paul Sartre, Varlık ve Hiçlik (Fenomenolojik Ontoloji Denemesi), Çev. Turhan Ilgaz, Gaye Ç. Eksen, İstanbul, İthaki Yayınları, 2011, s.691.

71 Metin Bal, Sartrém Varoluş̧u Felsefesi ve Dava Edebiyatı Teorisi, Felsefe Arkivi - Archives of Philosophy, Sayı: 50, İstanbul Üniversitesi Yayını, 2019, s 28-29. 
Hakem Değerlendirmesi: Dış bağımsız.

Çıkar Çatışması: Yazar çkar çatış,ması bildirmemiş,tir.

Finansal Destek: Yazar bu çalışma için finansal destek almadığını beyan etmiştir.

Peer-review: Externally peer-reviewed.

Conflict of Interest: The author has no conflict of interest to declare.

Grant Support: The author declared that this study has received no financial support.

\section{Kaynaklar}

Abalı, Funda. "Jean-Paul Sartre’ın Tiyatro Yapıtlarında Varoluşçu Felsefe ve Fenomenolojik Sanat Anlayışı”. Yüksek lisans tezi, Dokuz Eylül Üniversitesi, 2017.

Bal, Metin, "Varoluşçuluk ve Hümanizm” Yazısında Sartre’ın Varoluşculuk Savunması". Dokuz Eylül Üniversitesi. Doktora Programı. Sanatta Modernizm ve Postmodernizm Ders Notları. 24 Nisan 2019.

Bal, Metin. "Sartre’ın Varoluşçu Felsefesi ve Dava Edebiyatı Teorisi”. Felsefe Arkivi 50 (2019): 17-29.

Eliot, T.S. “Jean-Paul Sartre, Varoluşçuluk Bir Hümanizmdir”. Hümanizmin Özü. Çeviren Ahmet Aydoğan. İstanbul: İz Yayıncılık, 2002.

Giacometti, Alberto. Yazılar. Çeviren Aykut Derman. İstanbul: Yapı Kredi Yayınları, 2015.

Sartre, Jean-Paul. Estetik Üzerine Denemeler. Çeviren Mehmet Yılmaz. Ankara: Doruk Yayınevi, 1998.

Sartre, Jean-Paul. Edebiyat Nedir?. Çeviren Bertan Onaran. İstanbul: Can Yayınları, 2008.

Sartre, Jean-Paul. Varlık ve Hiçlik: Fenomenolojik Ontoloji Denemesi, Çeviren Turhan Ilgaz, Gaye Ç. Eksen, İstanbul: İthaki Yayınları, 2011.

Sartre, Jean-Paul. Varoluş̧̧uluk, Çeviren Asım Bezirci, İstanbul: Say Yayınları, 1985.

Sökmen, Sema. "Fenomenolojik Ontoloji Temelinde Jean-Paul Sartre’ın Sanat Anlayışı”, Yüksek lisans tezi, Adnan Menderes Üniversitesi, 2013.

Şan, Emre. “Sartre ve Giacometti: Varoluşçu Sanat Üzerine Düşünceler”, Felsefi Düşün 12 (2019). 


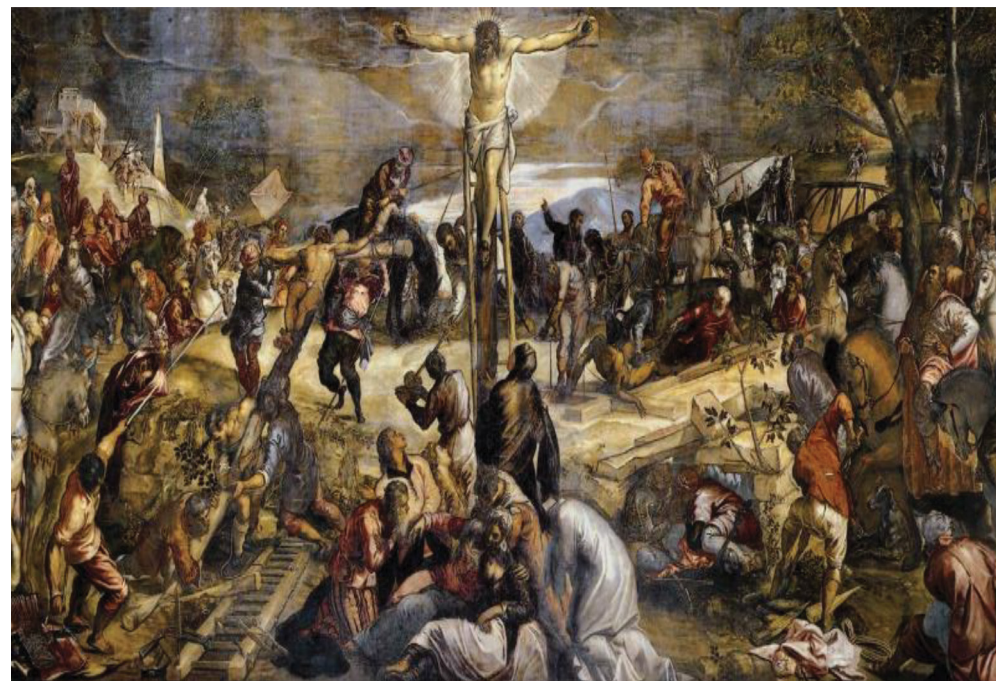

Şekil 1. Jacobo Tintoretto (1518-1594), Çarmışa Geriliş (The Crucifixion) (1565),

Scuola Grande di San Rocco, Venedik, İtalya

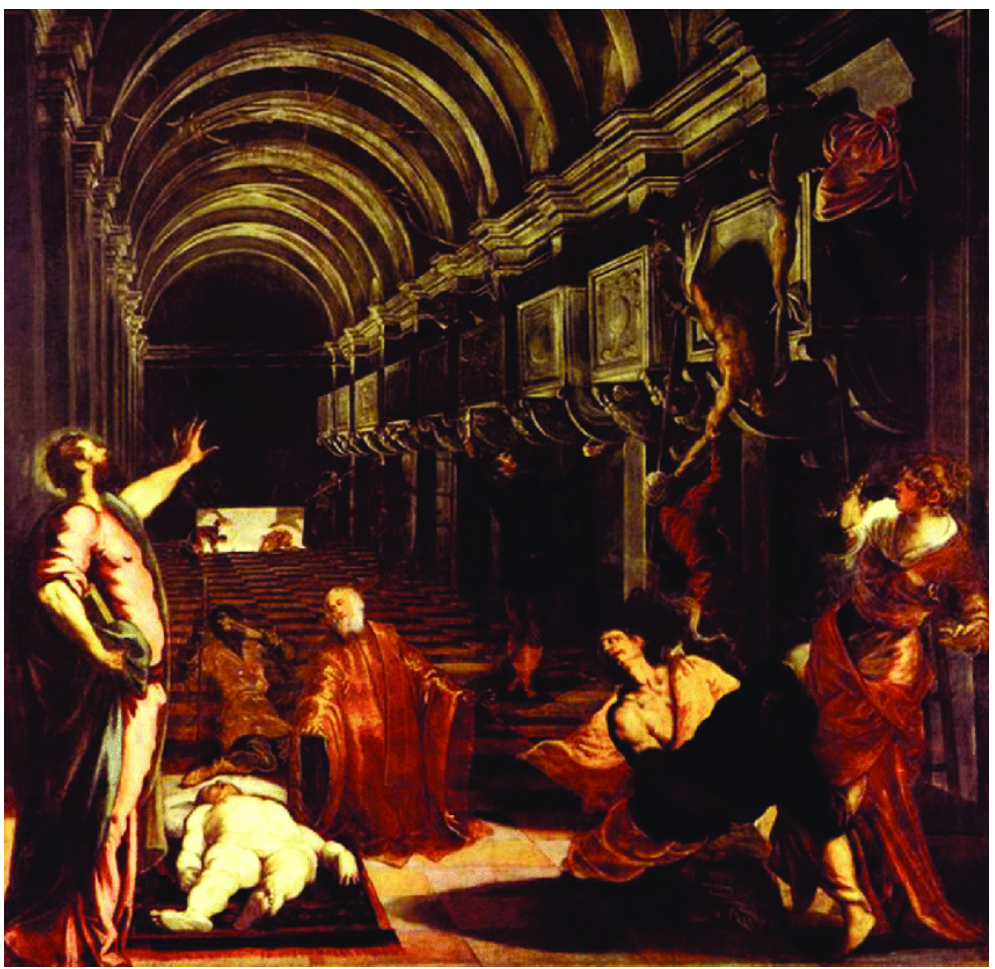

Şekil 2. Jacobo Tintoretto (1518-1594), Aziz Marcus'un Mucizesi (1562), Pinacoteca di Brera, Milano, İtalya 


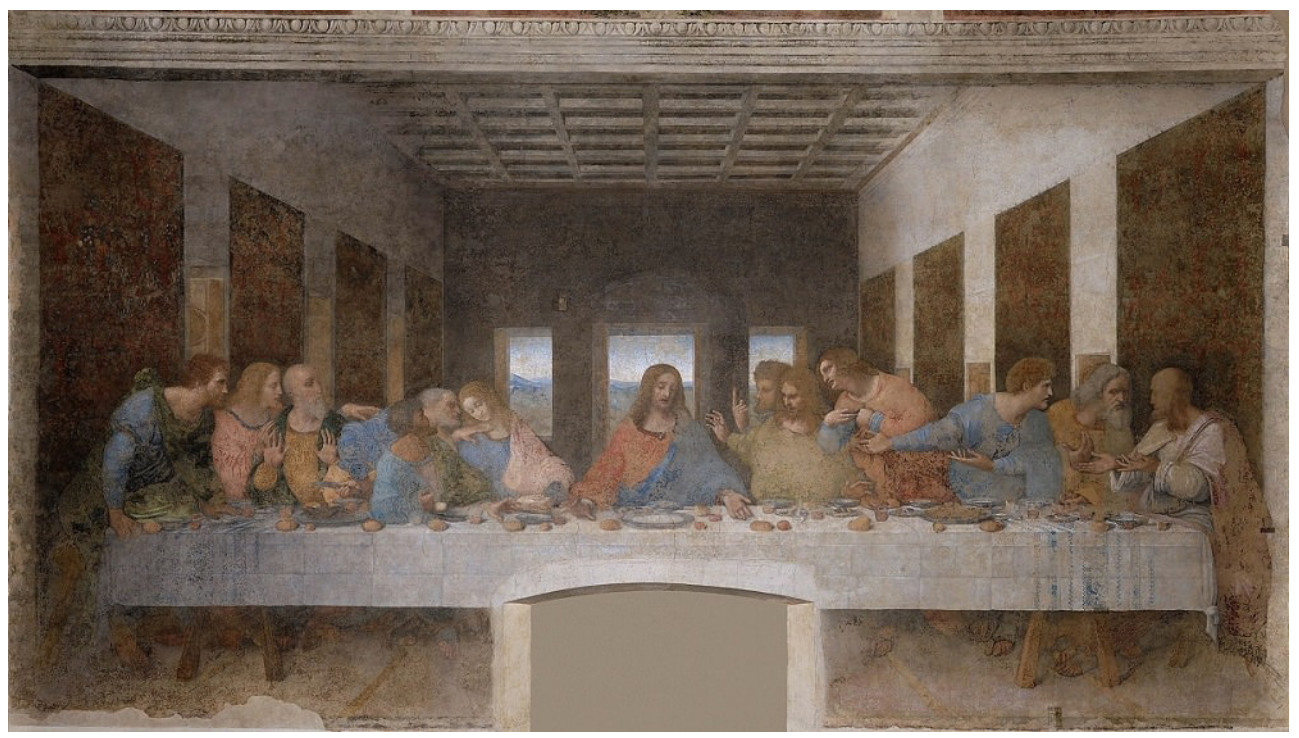

Şekil 3. Leonardo da Vinci (1452-1519), Son Akşam Yemeği (1495), Santa Maria delle Grazie, Milano, İtalya

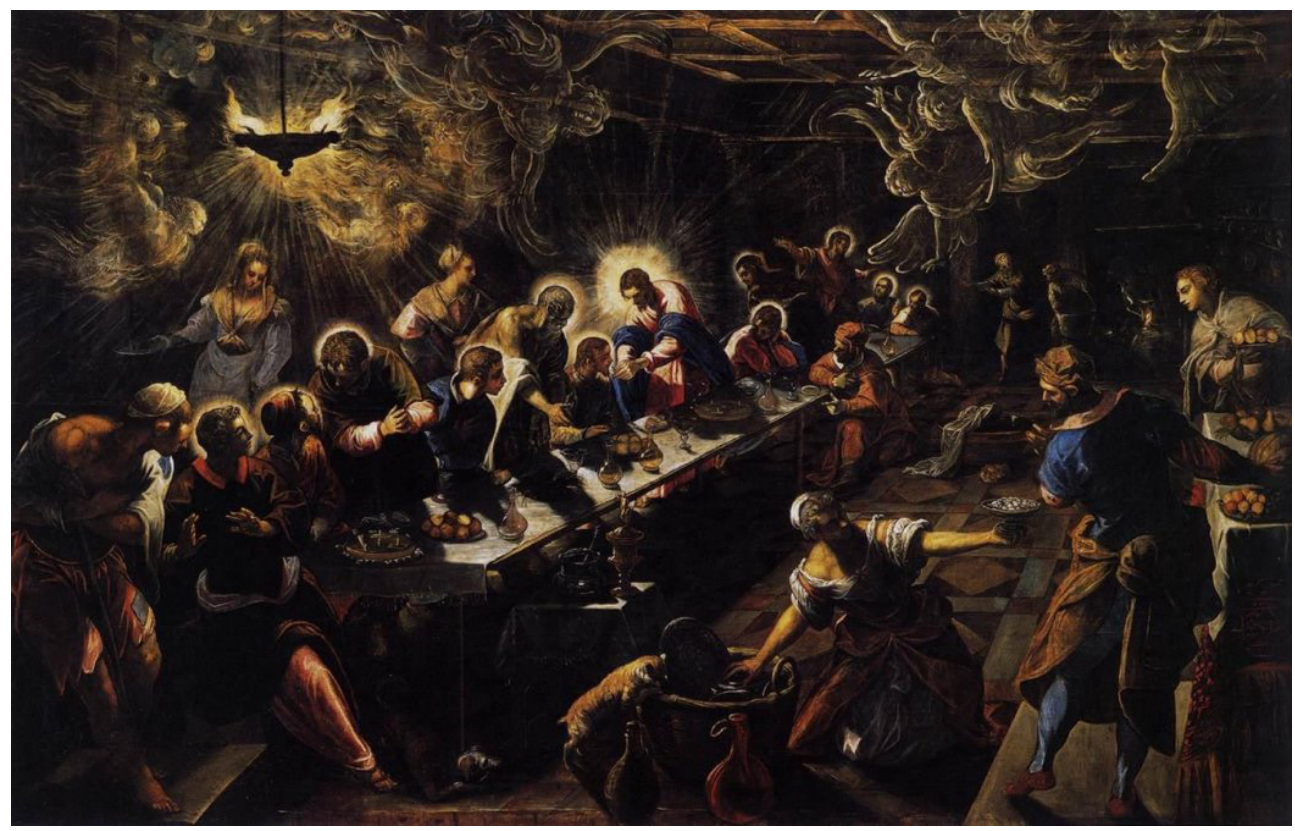

Şekil 4. Jacobo Tintoretto (1518-1594), Son Akşam Yemeği (1592), San Giorgio Maggiore Kilisesi, Venedik, İtalya 


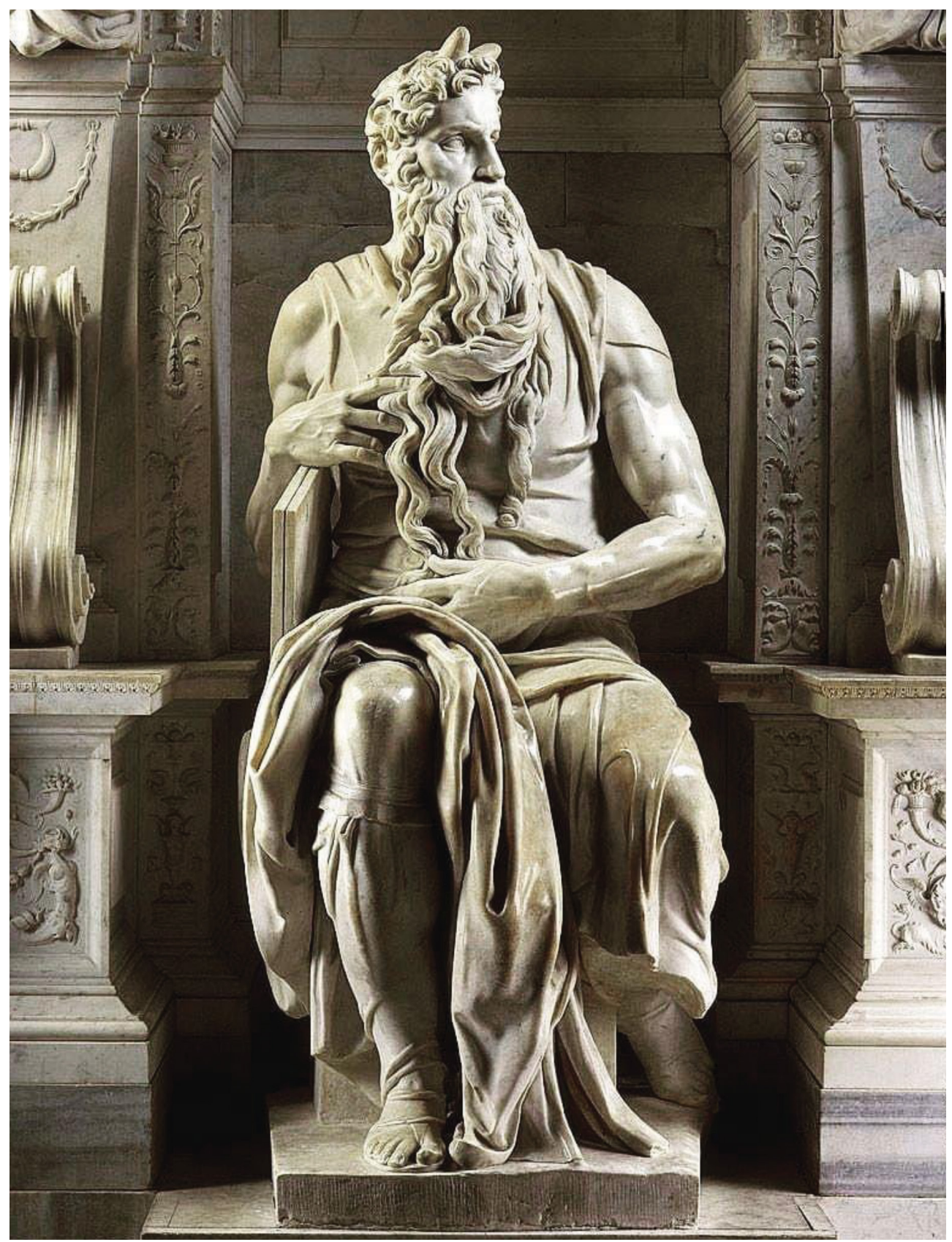

Şekil 5. Michelangelo (1475-1564), Musa’nın Hükmü (1513), San Pietro in Vincoli, Roma, İtalya 


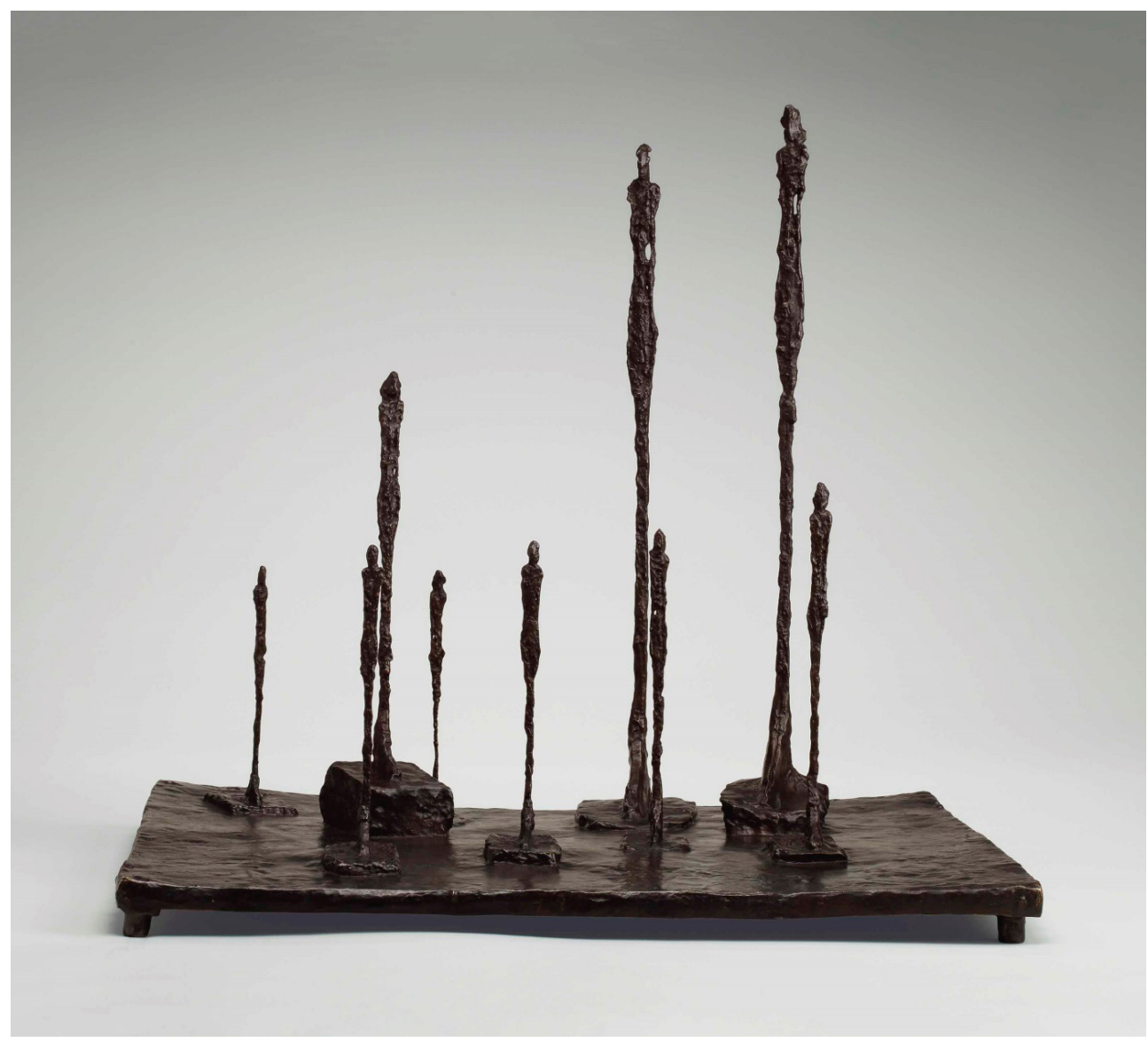

Şekil 6. Alberto Giacometti (1901-1966), Kalabalık Kompozisyon (1950), Jan Krugier Gallery, New York Amerika 


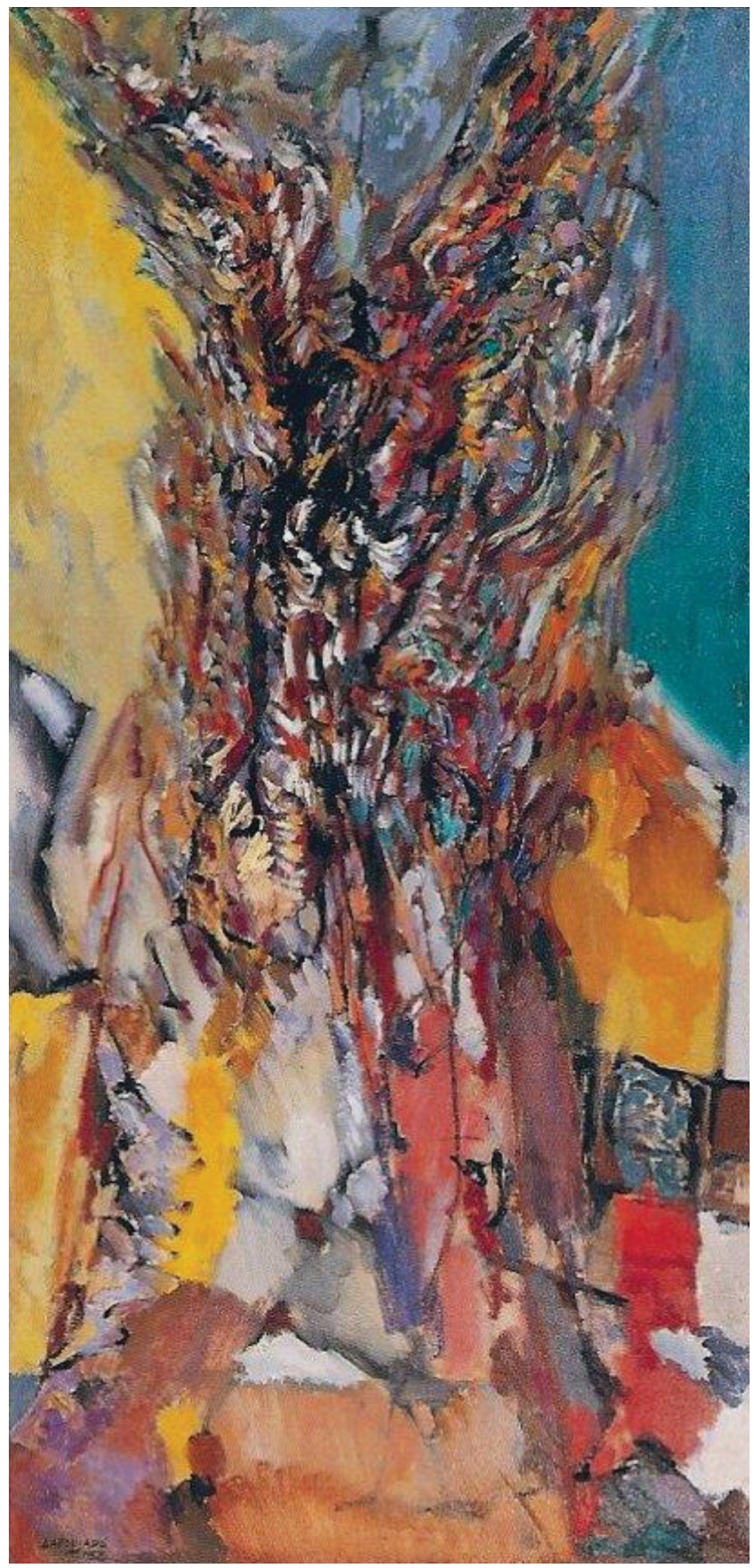

Şekil 7. Robert Lapoujade (1921-1993), İşkence (La Torture) (1958), Collection Barbatre, Paris, Fransa 


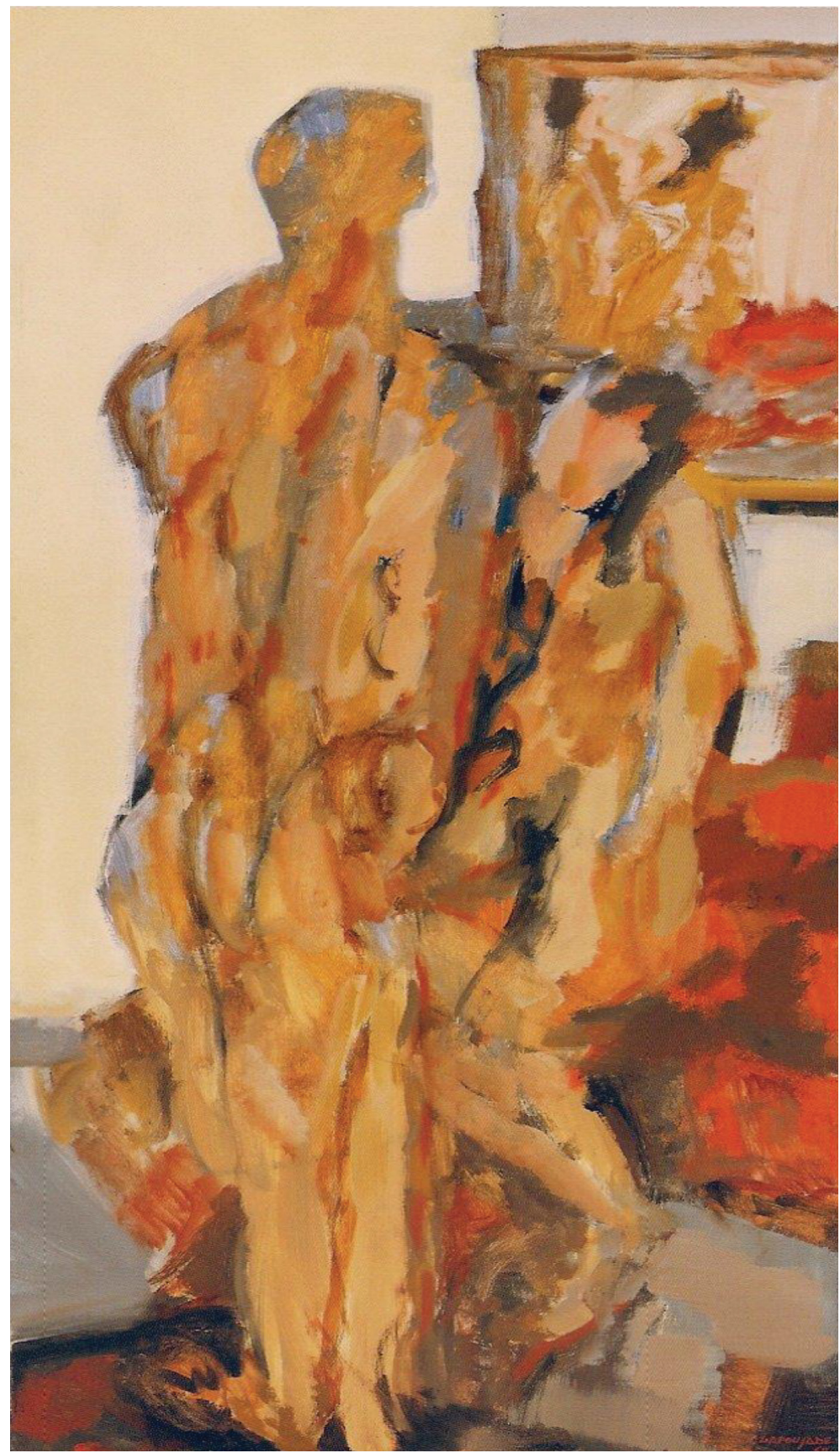

Şekil 8. Robert Lapoujade (1921-1993), Aynalı Çift (Le couple au miroir) (1968), Paris Musées Collections 


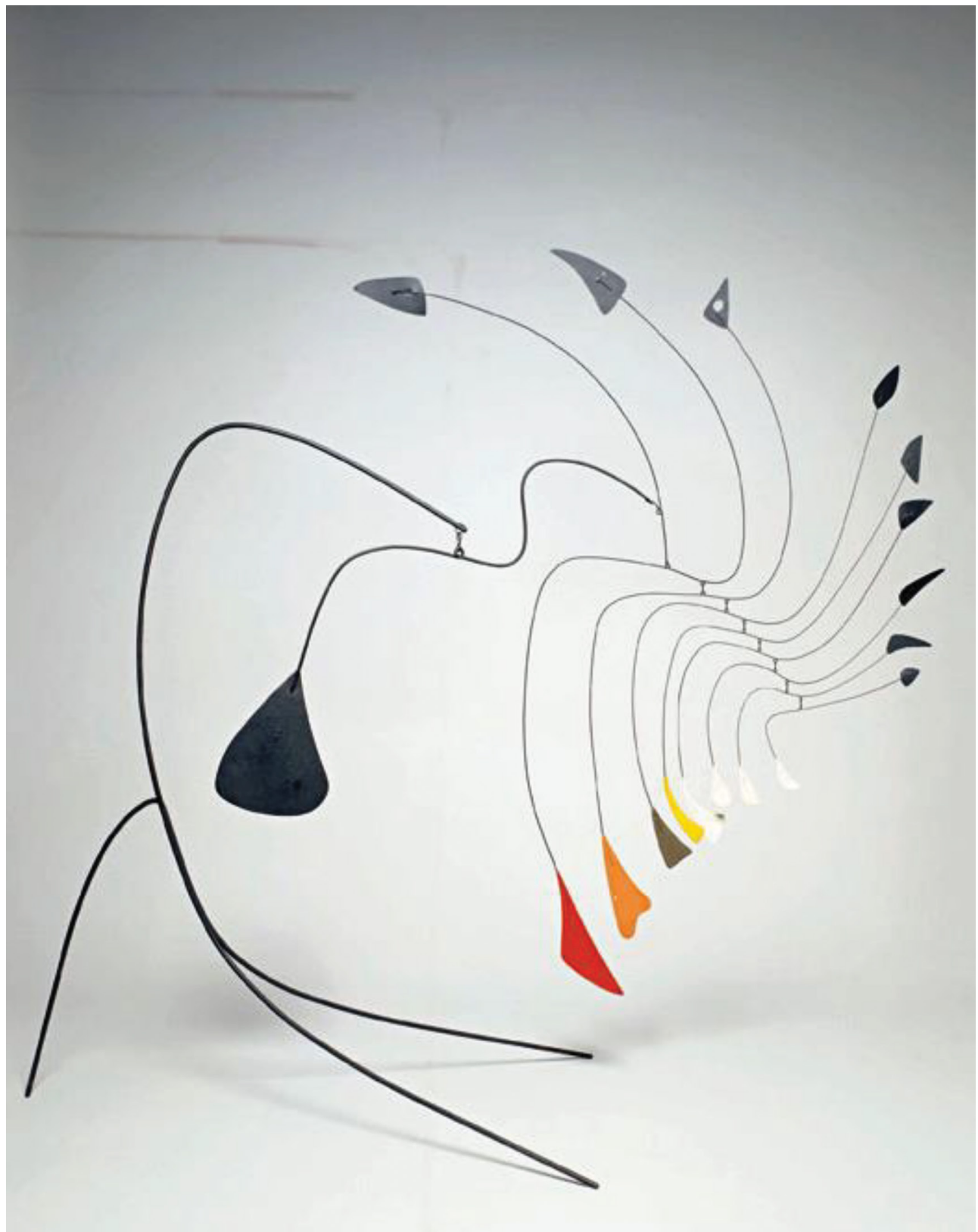

Şekil 9. Alexander Calder (1898-1976), Küçük Örümcek (The Little Spider) (1939), New York, Amerika 
